\title{
REGULATORY ISSUES \\ AFFECTING MANAGEMENT OF PRODUCED WATER FROM COAL BED METHANE WELLS
}

\author{
PREPARED FOR: \\ U.S. DEPARTMENT OF ENERGY \\ OFFICE OF FOSSIL ENERGY \\ UNDER CONTRACT W-31-109-ENG-38 \\ PREPARED BY: \\ JOHN A. VEIL \\ ARGONNE NATIONAL LABORATORY
}

FEBRUARY 2002 
$\underline{\text { Introduction }}$

Coal bed methane (CBM) wells are being developed in increasing numbers throughout the United States. These are wells that are drilled into coal seams to withdraw ground water (produced water) to reduce the hydrostatic pressure on the coal seam. The reduced pressure allows methane gas to migrate to the well bore where it moves to the surface and is collected. Where possible, operators prefer to discharge the produced water into nearby streams, rivers, or other surface water bodies. Depending on the chemical characteristics of the produced water, different levels of treatment are applied to the produced water before discharge. In some locations, produced water cannot be discharged and is injected, reused, or evaporated.

Although the CBM industry is producing "natural" gas, such gas may not necessarily be covered under the existing national regulations for discharges from the oil and gas industry. This paper describes the existing national discharge regulations, the ways in which CBM produced water is currently being managed, the current $\mathrm{CBM}$ discharge permitting practices, and how these options might change as the volume of produced water increases because of the many new wells being developed.

\section{Existing National Discharge Regulations}

NPDES permits: The primary U.S. law affecting water quality and water pollution control is the Clean Water Act. The Clean Water Act requires that all discharges of pollutants to surface waters (streams, rivers, lakes, bays, and oceans) must be authorized by a permit issued under the National Pollutant Discharge Elimination System (NPDES). Individual NPDES permits can be issued to specific facilities, or general NPDES permits can be issued that cover all similar activities located in the same geographic area. Most states have been delegated the authority to administer the NPDES program. Consequently, permits must follow not only the federal regulations but also any additional state regulatory requirements.

The heart of an NPDES permit is its numerical effluent limits. These limits describe what pollutants must be monitored and what is an acceptable quantity or concentration of the pollutants. Effluent limits are developed by considering both (a) technology-based limits developed to comply with applicable effluent limitations guidelines (ELGs) and (b) water quality-based limits.

Figures 1 through 4 outline the process used by permit writers to establish NPDES permit limits and conditions. Figure 1 shows that technology-based limits must be developed first; they serve as a minimum set of requirements. Figure 2 describes the actions that are taken to develop the technology-based limits. Figure 3 shows the process used to determine if water quality-based limits are necessary, and, if so, the process to calculate these limits. Finally, Figure 4 indicates that other permit conditions, like monitoring and reporting requirements, best management practices, and operational requirements, are added to the permit after the numerical limits are established. 
$\boldsymbol{E L G}$ - ELGs are national technology-based minimum discharge requirements. These standards are developed by the U.S. Environmental Protection Agency (EPA) on an industry-by-industry basis and represent the greatest pollutant reductions that are economically achievable for an industry sector or portion of the industry. Selection of ELGs involves consideration of technologies that have already been demonstrated in industrial applications, costs and economic impacts, and non-water-quality environmental impacts. The ELGs are applied uniformly to every facility within the industrial sector, regardless of where in the country the facility is located or the condition of the water body receiving the discharge. Existing facilities must meet a level of performance known as best available technology (BAT), while new facilities must meet new source performance standards (NSPS).

The EPA has developed ELGs for most major industrial categories. For the oil and gas industry, the EPA developed separate ELGs for onshore activities in 1979, offshore activities in 1993, and coastal activities in 1996. Special provisions for discharges from offshore wells drilled using synthetic-based drilling fluids were added in 2000. These ELGs are compiled into the Code of Federal Regulations as 40 CFR Part 435.

This paper is concerned only with onshore CBM activities. Three subcategories of Part 435, which covers the oil and gas industry, deal with onshore activities. The first is Subpart C, the onshore subcategory. The requirements for produced water in this section are very clear: no discharges are permitted. The other two subcategories provide exceptions to the onshore subcategory. Subpart E is the agricultural and wildlife water use subcategory, which applies to facilities located in the continental United States west of the 98th meridian, for which produced water is clean enough to be used for wildlife and livestock watering or other agricultural uses. The 98th meridian extends from near the eastern edge of the Dakotas through central Nebraska, Kansas, Oklahoma, and Texas. Produced water with a maximum oil and grease limit of $35 \mathrm{mg} / \mathrm{L}$ may be discharged from such sites. One caveat to this subcategory is that the produced water must be of good enough quality to be used for wildlife or livestock watering or other agricultural uses and must actually be put to such use during periods of discharge.

The second subcategory that permits onshore discharges is Subpart F, the stripper subcategory (40 CFR 435.60). This subcategory applies to facilities that produce 10 barrels per day or less of crude oil. The EPA has published no national discharge standards for this subcategory, effectively leaving any regulatory controls to states or EPA regional offices, depending on which has NPDES primacy. The EPA's decision to provide an exception for small oil wells reflects the economic burden that an across-the-board zero discharge standard would impose. The stripper subcategory is inconsistent in that it applies only to small oil wells and not to small (marginal) gas wells (typically 60 thousand cubic feet [MCF] per day or less). In the absence of any regulatory exception for marginal gas well discharges, such discharges are prohibited by the general onshore standards.

Permit writers may face situations in which no ELGs have been developed for entire industries, industry segments, or particular waste streams. In these circumstances, the permit writers must 
use their professional judgment (BPJ) to develop an ELG-equivalent technology-based limit (Figure 2). Under a BPJ permit, the permit writer can start from scratch or can borrow limits from other ELGs that have some relevance to the situation under consideration.

Water-quality-based limits - The Clean Water Act does not prohibit discharges of materials that can be considered toxic, like metals and organic chemicals. Instead, the Clean Water Act prohibits the discharge of toxic substances in toxic quantities. This goal is accomplished through water-quality-based effluent limits that make sure ambient receiving water concentrations of contaminants are low enough to maintain the designated use of the waters (e.g., drinking water supply or aquatic life protection).

ELGs serve as a foundation for the effluent limits included in a permit, but the ELGs are based on the performance of a technology and do not address the site-specific environmental effects of discharges. In certain instances, the technology-based controls may not be strict enough to ensure that the aquatic environment will be protected against toxic quantities of substances. In these cases, the EPA must include additional, more stringent water quality-based effluent limits in NPDES permits (Figure 3). These water-quality-based limits may be numeric or narrative (for example, "no toxic substances in toxic quantities"). The EPA has published numeric water quality criteria for more than 100 pollutants that can be used to calculate water-quality-based limits, and states have adopted many of these into their own water quality standards. The procedures for setting these limits take into account the designated use of the water body, the variability of the pollutant in the effluent, species sensitivity for protecting against toxicity, and, where appropriate, the available dilution in the receiving water.

Other NPDES permit conditions - To a large extent, facilities are responsible for taking the steps necessary to demonstrate compliance with NPDES permit limits. Permits instruct each facility operator on the frequency for collecting wastewater samples, the location for sample collection, the pollutants to be analyzed, and the laboratory procedures to be used in conducting the analyses. Detailed records of these "self-monitoring" activities must be retained by the facility for at least three years. Furthermore, each facility is required to submit the results of these analyses to the EPA on a periodic basis. For most facilities, the reporting frequency is monthly or quarterly, but in no case may it be less than once per year. Failure to meet the permit limits can result in fines or loss of the permit.

NPDES permits may also include operational or environmental effects monitoring requirements. Examples of these include preparing best management practices plans or spill prevention plans; conducting additional monitoring of the discharges, sediments, or fish tissues; and restrictions on the rate of discharge based on the receiving water flow (Figure 4).

\section{Current Produced Water Management Practices}

Alabama -- CBM production began as a mine safety effort rather than as a mechanism to recover methane. Research in Alabama in the mid-1970s indicated that methane could be drawn out of coal seams by dewatering the seams. At that time, the price of natural gas was very low and the 
gas was discarded. Following the Arab oil embargo in the late 1970s, as gas prices rose, there was a greater desire to capture and sell the methane from coal beds. Much of the early CBM development occurred in Alabama. Alabama operators recognized that an economic means of disposing of the produced water was critical to the viability of their fledgling industry. In the early 1980s, a group of Alabama producers petitioned the EPA for relief from the oil and gas ELGs. ${ }^{1}$ Alabama is located east of the $98^{\text {th }}$ meridian, so the agricultural and wildlife water use subcategory was not applicable. The stripper subcategory was only open to small oil wells, and the general onshore subcategory called for zero discharge. The producers argued that if the same coal bed was mined through conventional mining methods, the water associated with the seam could be discharged under an NPDES permit reflecting the coal mining ELGs. The EPA concurred with this position and further noted that when it had developed its onshore oil and gas ELGs, it had not performed a technical or economic analysis of the CBM sector. Therefore, at least for Alabama, CBM produced water was not considered to be regulated under Part 435, and operators could discharge the produced water.

Western States - The CBM industry in western states lacks the long-term history with produced water discharges that Alabama has had. As the CBM industry has increased in recent years in western states, various options for produced water management have been explored. Unlike the climate in Alabama, the climate in Wyoming, Montana, Colorado, and New Mexico is arid, and evaporation can be utilized. Furthermore, water is a scarce commodity in many western states, and the produced water can possibly be reused.

Information on actual produced water disposal practices from several CBM operations in Wyoming is available on EPA Region 8's website at:

http://www.epa.gov/region08/water/wastewater/npdeshome/cbm/gillette_operatiorn.PDF. The disposal methods discussed there include:

- discharge to stream following treatment;

- storage in ponds, reservoirs, and tanks, and then evaporation;

- livestock watering;

- crop irrigation;

- water enhancement work at wells;

- constructed wetlands;

- deep injection wells; and

- aquifer storage and retrieval using shallow injection wells.

The technical feasibility and cost of these options varies at different locations. Operators are likely to select the least-cost options that are authorized by state permitting authorities.

${ }^{1}$ Personal communication between John Veil and Stan Graves, President, Graco Resources Inc., Birmingham, AL, December 3, 2001. 


\section{Permitting Issues and Limits}

If produced water is discharged to streams or other surface water bodies, it must be authorized by an NPDES permit. The permit writer must first determine the applicable technology-based limits and then add water-quality-based limits as necessary.

Alabama - The Alabama Department of Environmental Management (ADEM) began issuing NPDES permits that were based on the coal mining ELGs and added other water quality-based limits. The following two paragraphs summarize portions of a May 1993 publication entitled "Coalbed Methane Produced Water Management Guide Treatment and Discharge to Surface Waters: Black Warrior Basin, Alabama."2

"In Alabama, the construction and operation of CBM wells are regulated by the State of Alabama Oil and Gas Board and CBM discharge permits are handled by the Water Division, Mining and Nonpoint Source Section of ADEM. Initial permits were based on total dissolved solids (TDS), and discharges were limited to an instream TDS concentration of $500 \mathrm{mg} / \mathrm{l}$. As the number of CBM wells increased sharply in the mid to late 1980s, ADEM began to enact more stringent discharge requirements to protect the water quality of the Black Warrior River.

In 1988, EPA published an Ambient Water Quality Criteria for Chloride which established a National Chloride Criterion of $230 \mathrm{mg} / \mathrm{l}$ and ADEM then adopted rules whereby applicants were permitted to release produced waters into surface streams if the instream concentration of chloride beyond a mixing zone would not exceed $230 \mathrm{mg} / \mathrm{l}$. However, because of the perceived difficulty in enforcing this standard the state developed a total loading criterion for CBM operations at the point of discharge. The allocation for each CBM operator was based on a calculated loading beginning at a point above the discharge, with additional allocations permitted downstream because of additional tributary waters provided dilution for additional chlorides. This procedure calculated the allowable mass loading [the number of pounds per day] for chlorides that will not exceed an instream concentration of $230 \mathrm{mg} / \mathrm{l}$. These permits were later referred to as Tier I permits. To allow growth while still protecting aquatic resources, CBM operators and ADEM jointly developed guidelines for instream monitoring of chloride concentration as the basis for additional NPDES permits. These permits were called Tier II permits and were issued with instream chloride concentration limits rather than the mass limits used in Tier I permits."

${ }^{2}$ Summary provided to John Veil by Carey Johnston, U.S. EPA Office of Water, Engineering Analysis Division on November 30, 2001. 
Information collected in $1997^{3}$ indicates that ADEM uses a baseline permit that can be customized for discharges to small streams. The permit is quite detailed and contains numerical limits for $\mathrm{pH}$, iron, manganese, biochemical oxygen demand, oil and grease, and dissolved oxygen; additional monitoring requirements for conductivity, chlorides, and effluent toxicity are included. Dischargers are required to install a diffuser on the end of their discharge pipes and to implement a best management practices plan. It appears that ADEM's permitting program has been effective and successful.

Western States (focus on EPA Region 8) - Much of the interest in this issue is focused on activities underway by EPA Region 8 to develop permitting guidance for CBM produced water. The EPA study is evaluating the technical feasibility and cost of allowing discharge with minimal treatment, discharge with beneficial use, discharge with advanced treatment (reverse osmosis is under consideration), and zero discharge (i.e., evaporation, shallow injection, or deep injection). The three key CBM-producing states in Region 8 (Colorado, Montana, and Wyoming) have received primacy to administer the NPDES program with the following exceptions. The EPA maintains permitting authority for Tribal lands in all three states and for Federal facilities in Colorado. The vast majority of CBM operations in those states will be on private lands or on Federal lands in Montana and Wyoming (primarily lands managed by the U.S. Bureau of Land Management [BLM]); therefore, NPDES permits will be issued by the state agencies. EPA's guidance, when completed, would be used by EPA permit writers for any permits on lands they regulate. EPA's guidance would be recommended but not required for any permits issued by the state agencies. However, given the active environmental organizations in Region 8, it is likely that state permits written with limits and controls less stringent than those recommended in EPA's guidance would be challenged. Thus, EPA's guidance could well become de facto regulatory controls.

In establishing technology-based limits, permit writers can elect to use the agricultural and wildlife water use ELGs directly and not seek exclusion from the oil and gas industry, as did the Alabama operators, because the Western states are located west of the $98^{\mathrm{th}}$ meridian. If permit writers use the agricultural and wildlife use ELGs directly, they must follow the caveat that the produced water must be of good enough quality to be used for wildlife or livestock watering or other agricultural uses and must actually be put to such use during periods of discharge. The second portion of this requirement raises additional issues. First of all, how could the produced water be used for agricultural or wildlife use? Some of the obvious answers include use in livestock watering tanks, use in ponds that serve as water supply for wildlife, and use for irrigation of crops. In a less direct way, such use could result from higher stream flow that would raise the water table and provide more consistent water to the roots of forage crops that are used by livestock or wildlife. There may be other ways of making this demonstration too. A permitting agency could be very strict on this point and require that a direct link must be shown,

\footnotetext{
${ }^{3}$ Veil, J.A., 1997, “Surface Water Discharges from Onshore Stripper Wells," prepared for U.S. Department of Energy, Office of Fossil Energy, December.
} 
or it could approve the discharge on the basis of general beneficial uses to local and downstream agriculture and wildlife.

A second important point is what time frame is meant by "during periods of discharge." This requirement could be interpreted as beneficially using the produced water in the same hour or day in which it is discharged. This interpretation would seriously restrict the applicability of these ELGs. Conversely, the time frame could be on the order of months or calendar quarters. This interpretation would allow for a greater range of opportunities to discharge under the ELGs.

Alternatively, a permit writer could establish technology-based limits through BPJ by using the agricultural and wildlife use ELGs or coal mining ELGs as a model or could conduct an independent analysis of technologies and economics. However, if the agricultural and wildlife use ELGs are chosen as a model for BPJ, the permit writer could choose to ignore the idea of beneficially reusing the produced water during periods of discharge.

CBM produced water, while typically much fresher than produced water from oil and gas wells, still contains parameters that can cause exceedances of state water quality standards (e.g., total dissolved solids [TDS], chlorides, barium, and others), or it could create problems when applied to soils through irrigation by virtue of an elevated sodium absorption ratio (SAR). There are concerns associated with discharges of large volumes of produced water to stream systems unaccustomed to high water levels. Consistently higher stream flows can lead to enhanced erosion or can cause the water table to rise allowing the roots of crops to come into contact with saltier water.

Some streams and rivers have relatively little assimilative capacity to handle the additional pollutant load from produced water. Even if CBM produced water discharges do not exceed water quality standards, they may lead to anti-degradation problems. ${ }^{4}$

Permitting in Wyoming - The Wyoming Department of Environmental Quality (DEQ) website has extensive information about CBM discharge application and permitting requirements. To summarize, it has issued individual NPDES permits and general NPDES permits that cover many similar discharges in the same geographic area. Currently, the DEQ has issued approximately 600 NPDES permits for CBM discharges covering nearly 3,000 different discharge points. ${ }^{5}$ It first issued a statewide general permit that had relatively stringent limits. So far, only 5 to 10 companies have applied for coverage under this general permit. Most companies have sought individual permits.

\footnotetext{
${ }^{4}$ Personal communication between John Veil and Dan Arthur, president, ALL Consulting, Tulsa, OK, December 3, 2001.

${ }^{5}$ Personal communication between John Veil and Kathy Shreve, Wyoming DEQ, Cheyenne, WY, on December 4, 2001.
} 
The DEQ has established a baseline set of requirements for all streams as well as additional stream-specific water-quality-based limits. The baseline requirements are shown in Table 1. Option 1a is for discharges to constructed upland reservoirs with no potential for discharges from the reservoir. Option $1 \mathrm{~b}$ is for discharges to reservoirs in areas that drain to closed basins. Option 2 is for discharges into Class II water systems. Basin-specific guidelines are provided in Table 2. Additional metals limits may be applied on the basis of the results of the representative sample submitted to the DEQ as part of the application package. The most current information on permitting options is a memorandum by Gary Beach, Administrator of the Water Quality Division, dated December 10, 2001. This, along with other CBM information, can be found at http://deq.state.wy.us/wqd/cbm.htm.

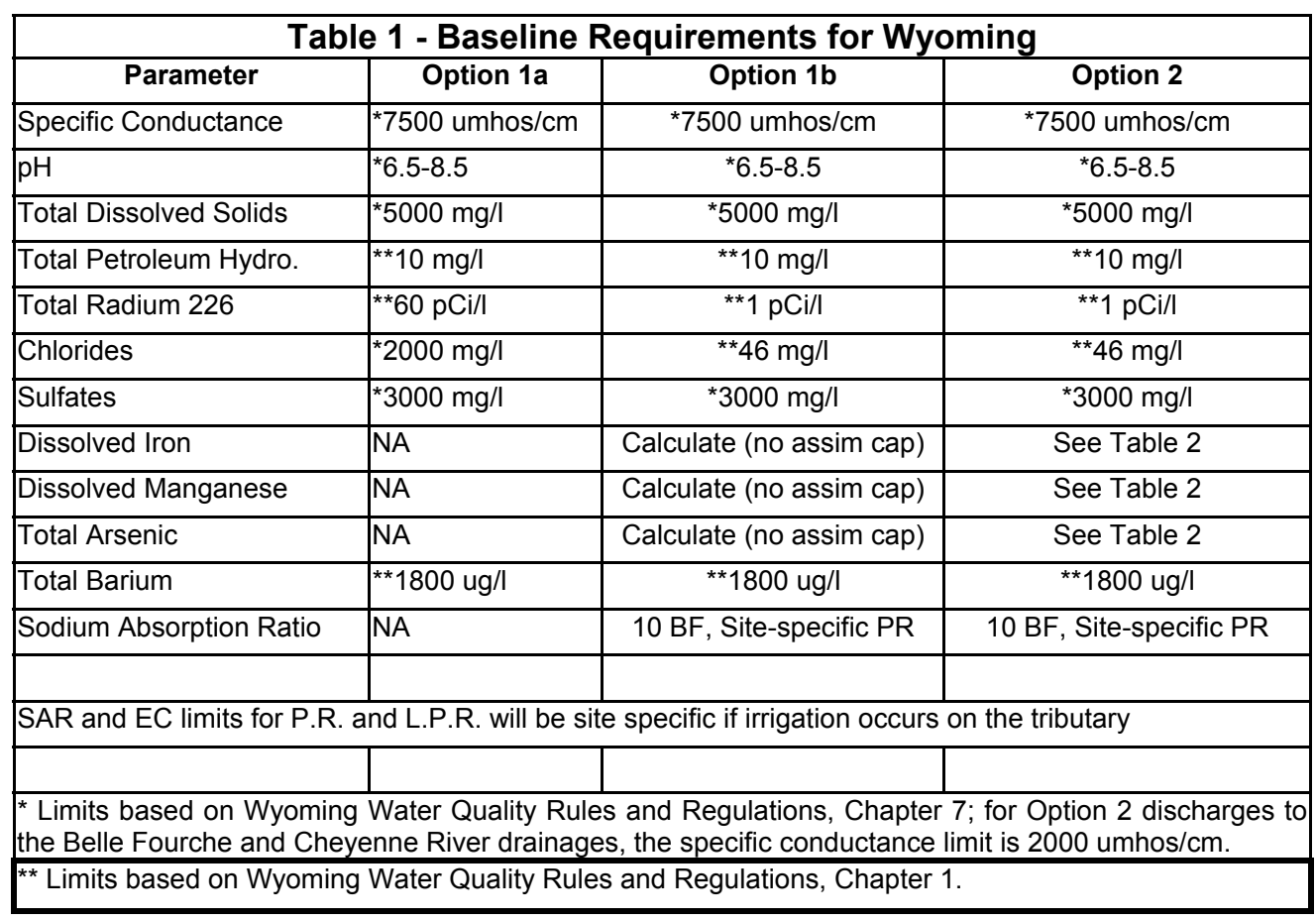

A January 30, 2001, memo from Leah Krafft, Wyoming NPDES Program Principal, notes that individual permits would rely on EPA's agricultural and wildlife use subcategory ELGs as the technology basis; therefore, applicants would need to submit documentation that the discharged water will be used for a specific agricultural or wildlife purpose (http://deq.state.wy.us/wqd/watershed/10294-doc.pdf). Ms. Krafft indicated that Wyoming is meeting the ELGs limit of $35 \mathrm{mg} / \mathrm{l}$ oil and grease on the basis of meeting a surrogate parameter of total petroleum hydrocarbons at the stricter level of $10 \mathrm{mg} / \mathrm{l}$. 


\begin{tabular}{|c|c|c|c|c|c|}
\hline Watershed & Station & $\begin{array}{l}\text { Dissolved } \\
\text { Iron ug/l }\end{array}$ & $\begin{array}{c}\text { Dissolved } \\
\text { Manganese ug/l }\end{array}$ & \begin{tabular}{|c|}
$\begin{array}{c}\text { Total Barium } \\
\text { ug } / \mathrm{l}\end{array}$ \\
\end{tabular} & $\begin{array}{c}\text { Total Arsenic } \\
\text { ug/l }\end{array}$ \\
\hline \multirow[t]{3}{*}{ Little Powder River } & Corral Creek & 237 & 786 & 1800 & 2.3 \\
\hline & Near Weston & 234.3 & 718.5 & 1800 & 3.6 \\
\hline & Weston & 253.4 & 718.6 & 1800 & 7 \\
\hline Watershed & Station & $\begin{array}{l}\text { Dissolved } \\
\text { Iron ug/l }\end{array}$ & $\begin{array}{c}\text { Dissolved } \\
\text { Manganese ug/l }\end{array}$ & \begin{tabular}{|c|} 
Total Barium \\
ug/l
\end{tabular} & $\begin{array}{c}\text { Total Arsenic } \\
\text { ug/l }\end{array}$ \\
\hline \multirow[t]{3}{*}{ Cheyenne River } & Dull Center & 249 & 873.9 & 1800 & 2.4 \\
\hline & Antelope Creek & 240 & 905.7 & 1800 & 2.4 \\
\hline & Black Thunder & 255.2 & 632.2 & 1800 & 5.7 \\
\hline Watershed & Station & $\begin{array}{l}\text { Dissolved } \\
\text { Iron ug/l }\end{array}$ & $\begin{array}{c}\text { Dissolved } \\
\text { Manganese ug/l }\end{array}$ & $\begin{array}{c}\begin{array}{c}\text { Total Barium } \\
\text { ug/l }\end{array} \\
\end{array}$ & $\begin{array}{c}\text { Total Arsenic } \\
\text { ug/l }\end{array}$ \\
\hline \multirow[t]{6}{*}{ Belle Fourche River } & Caballo Creek & 236.6 & 755.9 & 1800 & 2.3 \\
\hline & Donkey Creek & 234.2 & 841.5 & 1800 & 3 \\
\hline & Belle Fourche & 275.3 & 818.1 & 1800 & 3.1 \\
\hline & Rattlesnake & 262.1 & 808.1 & 1800 & 2.7 \\
\hline & Dry Creek & 284 & 861.9 & 1800 & 3.3 \\
\hline & Moorcroft & 274.5 & 790.4 & 1800 & 3.1 \\
\hline Watershed & Station & $\begin{array}{l}\text { Dissolved } \\
\text { Iron ug/l }\end{array}$ & $\begin{array}{c}\text { Dissolved } \\
\text { Manganese ug/l }\end{array}$ & \begin{tabular}{|c|} 
Total Barium \\
ug/l
\end{tabular} & $\begin{array}{c}\text { Total Arsenic } \\
\text { ug/l }\end{array}$ \\
\hline \multirow[t]{4}{*}{ Powder River } & Sussex & 248.6 & 646.4 & 1800 & 7 \\
\hline & Arvada & 299.7 & 629 & 1800 & 7 \\
\hline & Crazy Woman & 116.6 & 69.4 & 1800 & 2.5 \\
\hline & Clear Creek & 123.9 & 36.6 & 1800 & 2.3 \\
\hline
\end{tabular}

Permitting in Montana - Montana has issued just one CBM NPDES permit to date. ${ }^{6}$ The permit, which can be found on the Montana DEQ website

(http://www.deq.state.mt.us/coalbedmethane/MT0030457.htm), places numerical average limits on total flow of 1,600 gallons per minute (gpm) and on total suspended solids of $30 \mathrm{mg} / \mathrm{l}$, and requires an acute toxicity test. Additional monitoring without limits is required for TDS, specific conductance, SAR, iron, dissolved aluminum, ammonia, fluoride, radium 226, and chloride. This particular permit involved extensive site-specific calculations to ensure that state water quality standards were not exceeded.

\footnotetext{
${ }^{6}$ Personal communication between John Veil and Tom Richmond, Administrator, Montana Board of Oil and Gas Conservation, Billings, MT, January 29, 2002.
} 
Permitting in Colorado - The Colorado Department of Public Health and Environment, Water Quality Division, has issued 12 NPDES permits for CBM discharges. They have very comprehensive limits set to achieve agricultural and water quality standards. The least stringent set of limits includes the following:

TDS - 3,500 mg/l

metals - limits on a full set of metals, unless applicant submits an analysis with the application boron - $2 \mathrm{mg} / \mathrm{l}$

copper $-0.2 \mathrm{~g} / 1$

manganese $-0.2 \mathrm{mg} / 1$

iron $-5 \mathrm{mg} / \mathrm{l}$

selenium - $0.02 \mathrm{mg} / 1$

zinc $-2 \mathrm{mg} / \mathrm{l}$

chlorides - 1,500 mg/

total suspended solids - $30 \mathrm{mg} / \mathrm{l}$ average and $45 \mathrm{mg} / 1$ maximum

$\mathrm{pH}$ range -6.5 to 9.0

whole effluent toxicity test each quarter

oil and grease $-10 / \mathrm{mg} / \mathrm{l}$.

If discharges are made to particularly sensitive streams, the limits may be much stricter than these. In addition, permittees must do a organic pollutant scan for every tenth discharge point. ${ }^{7}$

Colorado uses the agricultural and wildlife use ELGs as its technology basis but has elected to use a stricter oil and grease limit than the $35 \mathrm{mg} / \mathrm{l} \mathrm{limit} \mathrm{in} \mathrm{the} \mathrm{ELGs.}$

\section{$\underline{\text { Discussion }}$}

Alabama has found a permitting approach that has been successful. It has used effluent limits that are economically achievable and stream flows that are adequate and available to assimilate the discharges.

The Region 8 states are still operating at the front edge of the CBM development curve. To date, there have been relatively few CBM discharges to permit, and state agencies can generally feel comfortable that they are issuing permits with suitable controls. However as a result of the rapid increases in the number of wells, the volume of new produced water, could if discharged, modify the hydrology and chemical characteristics of ecological systems that have evolved in waterscarce regions. In a similar vein, western communities and culture have developed under waterscarce conditions. If the availability of surface and near-surface ground water were suddenly magnified, the existing social and commercial systems could be strained. Apparently these factors are contributing to concerns that produced water discharges are having or could have

\footnotetext{
${ }^{7}$ Personal communication between John Veil and Chris Gates, Colorado Water Quality Control Division, Denver, CO, December 6, 2001.
} 
negative impacts. Several examples are described in a draft report posted on Region 8's website at: http://www.epa.gov/region08/water/wastewater/npdeshome/cbm/gillette_landowner.pdf. The problems described include:

- An influx of salty water to ditches and tributaries can kill vegetation in ditches and lead to an elevated water table.

- An elevated water table with a higher SAR or chlorides content may influence the ability of soils to support crops necessary to maintain livestock production.

- An elevated water table can change the stability of surface soils, so that foundations shift and crack.

- Spills or ponding of produced water on soils can kill vegetation.

Rapid increases in permit applications could overwhelm state permitting agencies and lead to backlogs in issuing permits. Unless alternatives to surface discharge are economically available, the CBM industry might not be able to grow at its desired rate. CBM operators might voluntarily choose to employ produced water management or disposal methods that do not involve NPDES permits to avoid project development delays and possibly strict and costly permit limits.

CBM operators favor as much flexibility in produced water management options as possible. A first step toward this goal is to identify geographic areas in which CBM discharges could be approved in a reasonable length of time or could be pre-approved under a general permit or other set of standardized limits, like those used in Alabama. Several different tiers of treatment requirements might be imposed at different locations on the basis of the characteristics of the produced water, its volume in relation to the stream flow, and other local factors, such as the availability of feasible beneficial reuse opportunities. There might be areas in which surface discharge would not be permitted because of soil or ecosystem sensitivity. In those areas, other types of produced water treatment or management would be necessary.

The information being collected by the EPA and its contractors should help in reaching these goals. The data should contribute to a better understanding of the technical feasibility and cost of different treatment or management options. 
Figure 1 - Establishing NPDES Permit Limits and Conditions - Simplified Overview

$\begin{aligned} & \text { Step } 1-\text { Develop technology-based } \\ & \text { limits }\end{aligned}$
$\begin{aligned} & \text { Step } 2 \text { - Develop water quality-based } \\ & \text { limits }\end{aligned}$
$\begin{aligned} & \text { Step } 3 \text { - Determine other permit } \\ & \text { conditions }\end{aligned}$

Figure 2 - Establishing NPDES Permit Limits and Conditions Step 1 - Develop Technology-based Limits

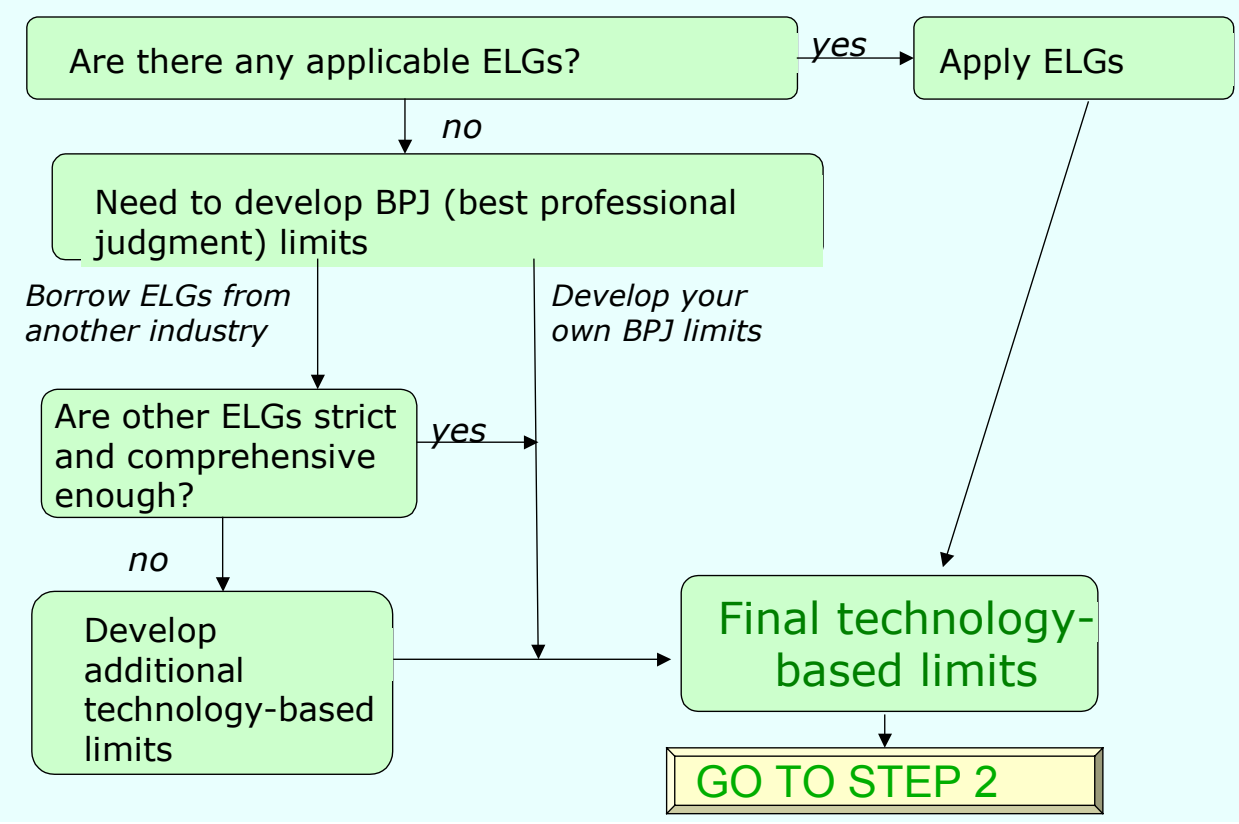


Figure 3 - Establishing NPDES Permit Limits and Conditions Step 2 - Develop Water Quality-based Limits

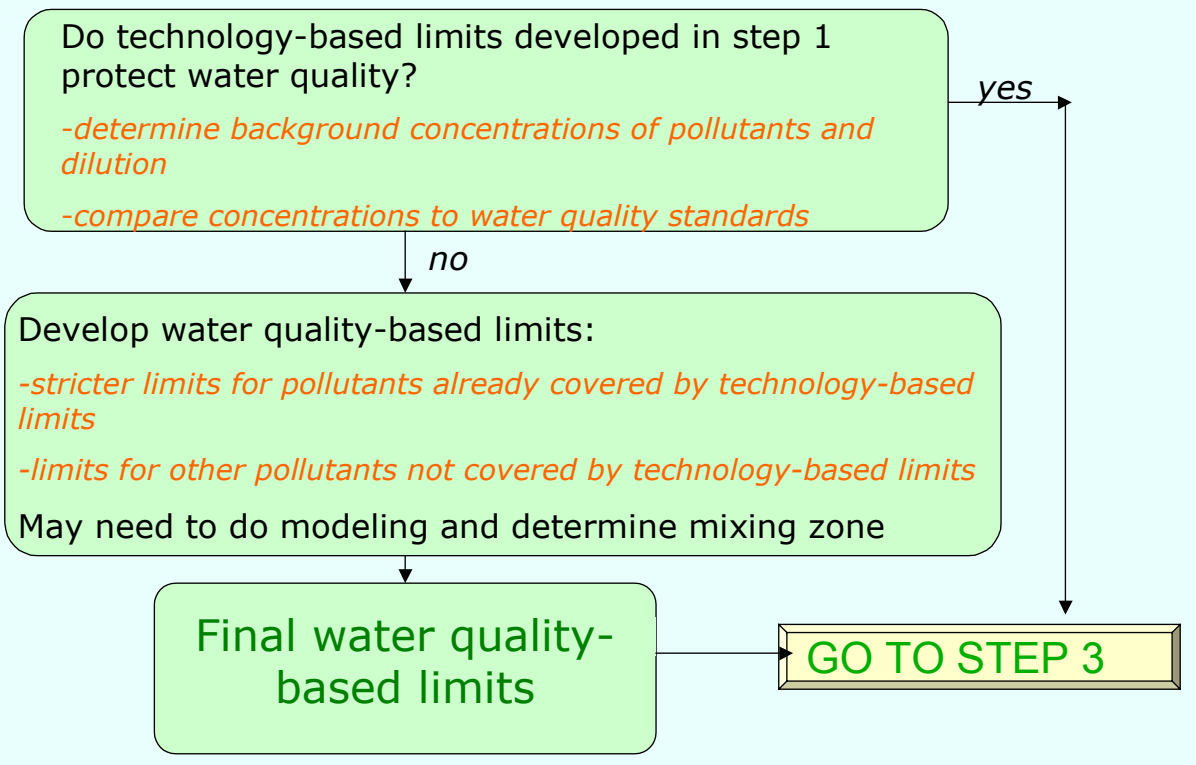

Figure 4 - Establishing NPDES Permit Limits and Conditions Step 3 - Determine Other Permit Conditions

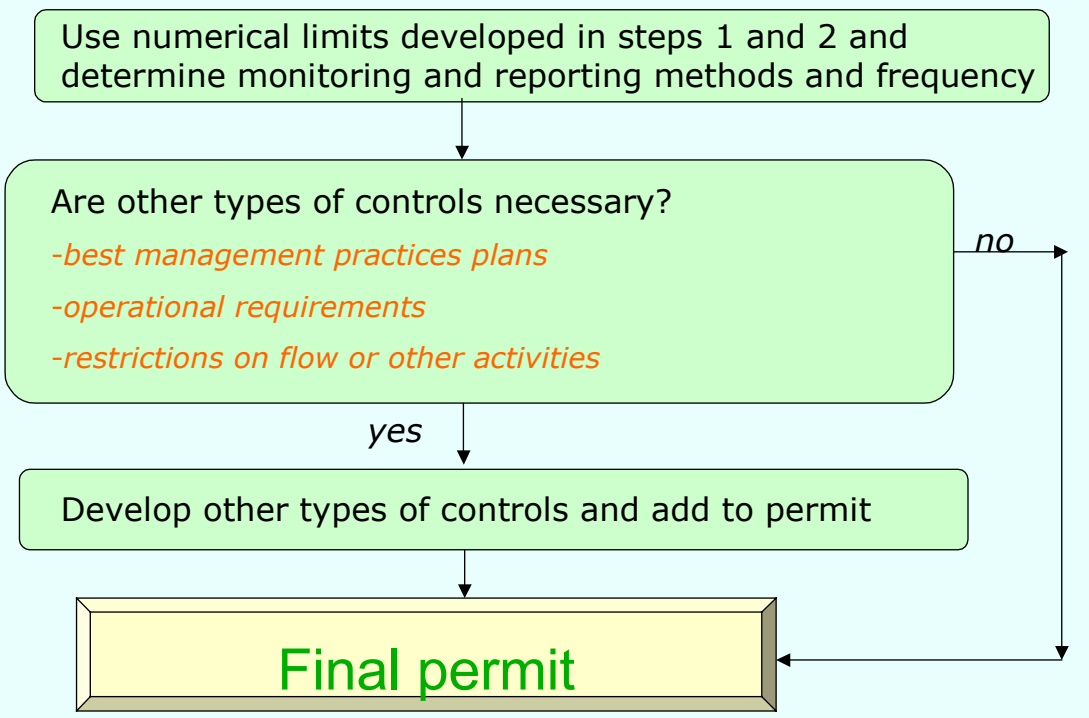

